\title{
A Comparative Study of Male and Female Distance Learners' Mathematics Achievement
}

\author{
Samuel Ebenezer Armah ${ }^{1}$ (D), Peter Akayuure ${ }^{2 *}$ (D), Robert Benjamin Armah ${ }^{2}$ (D)
}

${ }^{1}$ Institute for Distance and e-Learning, Education University of Education, Winneba, GHANA
${ }^{2}$ Department of Mathematics Education, University of Education, Winneba, GHANA
* Corresponding Author: pakayuure@gmail.com

Citation: Armah, S. E., Akayuure, P., \& Armah, R. B. (2021). A Comparative Study of Male and Female Distance Learners' Mathematics Achievement. Contemporary Mathematics and Science Education, 2(1), ep21001. https://doi.org/10.30935/conmaths/9288

\begin{abstract}
The purpose of this Ex Post facto study was to investigate the difference in mathematics achievement between male and female learners offering Diploma in Basic Education (DBE) by distance at the Institute for Distance and eLearning (IDeL), University of Education, Winneba (UEW). Three consecutive year cohort groups (i.e. 2015, 2016 and 2017) of DBE distance learners were purposively selected from all the forty distance education centers of IDeLUEW. There were 6,468, 3,483 and 3,276 learners in the 2015, 2016 and 2017 year groups respectively. This gave a sample size of 13,227 distance learners for the study. The End-of-semester mathematics examinations grades of the learners in Math I and Math II were retrieved from the UEW-IDeL registry and analysed comparatively using ChiSquare tests. Generally, the results show a below average performance in mathematics for both genders. However, there were statistically significant differences in the achievement of Mathematics between male and female distance learners in each of the three years with the males attaining higher grades than their female counterparts. It is recommended that teacher education institutions engaged in distance programmes should pay special attention to the gender gap in mathematics achievement and adopt strategies to motivate them to pursue the subject.
\end{abstract}

Keywords: distance learners, gender, Mathematics achievement

Received: 13 Jul. $2020 \bullet$ Accepted: 25 Aug. 2020

\section{INTRODUCTION}

All over the world, colleges of education and teacher education universities are mandated to train teachers for various levels of education. This is often done by the traditional face-to-face mode or throughout open and distance learning modes. Open and distance education is fast becoming an accepted and indispensable part of the main-stream of educational systems in both developed and developing countries (United Nations Educational, Scientific and Cultural Organization (UNESCO), 2002). Currently, there has been particular emphasis on the latter in teacher education even though there are disputes about the quality of graduates from distance programmes.

The Distance Education (DE) programmes are being run for more than a decade in five out of its nine public universities in Ghana; University of Education, Winneba (UEW), University of Cape Coast (UCC), University of Ghana (UG), University for Development Studies (UDS) and Kwame Nkrumah University of Science and Technology (KNUST). DE programmes in Ghana were first introduced by UEW in 1992 under the Institute for Educational Development and Extension (IEDE) created by the Centre for Distance Education (CDE) in response to the challenge of providing increased opportunities for tertiary education (Mensah \& Owusu-Mensah, 2002). The name of the institute has recently been changed to the Institute for Distance and e-Learning (IDeL) as a result of the inclusion of electronic learning opportunities to satisfy the needs of students and demands of modern society (IDeL Admission Brochure, 2019). UCC later joined in offering the DE programmes to students. These two public universities are at the forefront of running DE programmes and have the largest student population so far as distance education programmes are concerned in Ghana. In fact, trends and patterns in enrolments show that UEW and UCC together account for over $70 \%$ of all distance enrolment in public universities in Ghana (Larkai, Ankomah-Asare, \& Nsowah-Nuamah, 2016).

The UEW Institute for Distance and e-Learning (UEW-IDeL) has 40 study centers spread across the sixteen regions of Ghana, with at least one center in each region. The Institute run Basic Education programmes, Post-Diploma Degrees as well as Master Degrees. The Institute also aims at increasing access to the Diploma in Basic Education (DBE) programme to serving teachers in the Ghana Education Service, such as teachers with Diploma, certificate "A", and "Pupil-Teachers" (untrained teachers). The mode of delivery of the DE programme is predominantly by print medium with effort to mount all courses on Moodle platform. There are also occasional face-to-face tutorials facilitated by a tutor during every other weekends. 
The UEW-DBE programme has been designed such that the students study mathematics (i.e. Math I and Math II) for the first two years in the three years they spend on the DBE distance programme. As a prerequisite, the mathematics courses are designed to enable all DBE learners acquire a strong mathematics content knowledge base up to the senior high school mathematics standard. By such strong content knowledge base, these distance learners, who are mainly teachers, irrespective of their gender, would be able to teach mathematics confidently and competently in the various basic schools.

\section{Learners' Mathematics Achievement and Gender}

Over the years, the issue of gender equity in mathematics achievement and career has been of great concern and has attracted much research. Gender is regarded by several researchers as an important factor in the learning of mathematics (Gunderson, Ramirez, Levine, \& Beilock, 2012; Halat \& Şahin, 2008; Wedege, 2007). Different results have been reported on gender and other variables such as age when comparing academic performance of DE and on-campus students. For example, Cheung and Kan (2002) reported that gender was significantly related to academic achievement while age was not in the DE setting. Barakzai and Fraser (2005) found no significant difference in academic performance between men and women on DE programme.

Abubakar and Oguguo (2011) investigated the correlation between age and gender on academic achievement of Mathematics and Science students using their Cumulative Grade Point Average (CGPA)). The study used two hundred and twenty-three (223) females and one hundred and nine (109) males. Scatter-plot, mean and Standard deviation were used for the descriptive statistics while univariate analysis of variance and multiple regression were used for the inferential statistics. Z-test was used to test the null hypothesis formulated. The result revealed a linear relationship between, ageCGPA and gender-CGPA. Low positive correlation coefficients were however obtained for ages and gender which were significant. The predictor variables jointly accounted for $1.3 \%$ of the variance, gender was the better predictor. However, the null hypothesis that no significant difference existed between gender and academic achievement of the students was accepted.

Erdoğan, Baloğlu and Kesici (2011) also explored gender differences in mathematics course achievement, geometry course achievement and geometry self-efficacy of 199 students. Mathematics and geometry end-of-the-year GPAs were obtained from official student records. Students responded to a set of brief demographic questions asking their gender in addition to the Self-efficacy Scale toward Geometry (SESTG). Data were screened for the assumptions of parametric statistics. In order to test mathematics and geometry endof-the-year achievement differences simultaneously, between men and women, a between-subjects MANOVA was used. A second MANOVA was used to test three dependent variables of self-efficacy beliefs simultaneously in a non-orthogonal design. Independent variable was gender. Results showed that there was a significant multivariate effect of gender on the combined dependent variables. There was a large association both between the dependent variables and gender. The results of univariate $\mathrm{F}$ analyses indicated that there were significant gender differences on both mathematics achievement and geometry achievement. Females achieved significantly higher than males.

Cunningham (2016) is of the view that current quantitative gender and mathematics ability and postsecondary access research exist in different literatures, each drawing different conclusions. But if they are studied together as a single model it may be possible to demonstrate unrecognized associations. Thus, using 106,473 standardized student test responses from a single cohort, Cunningham (2016) investigated the likelihood of enrolling in Grade 9 academic mathematics against elementary achievement and gender in a single logistic regression model. Results indicated that males achieved higher, and occupied both achievement extremes in greater numbers, while females were 1.5 times more likely to enrol in mathematics courses.

Despite the numerous studies that have investigated such areas of the DE programme, little is known about the difference in mathematics achievement of male and female DE learners in developing countries like Ghana. This study was aimed at determining if there were any significant differences in mathematics achievement between male and female DBE distance learners at the UEW-IDeL.

\section{Problem Statement}

Comparative studies, both national and international, have reported below benchmark achievements among Ghanaian basic school students in mathematics (Anamuah-Mensah \& Mereku, 2005; Anamuah-Mensah, Mereku, \& Asabere-Ameyaw, 2008; Butakor, Ampadu, \& Cole, 2017; Gunhan, 2014; Mullis, Martin, \& Foy, 2008). Studies have shown that academic achievement has several determinant extending from socio-economic status (Barakzai \& Fraser, 2005), learning disabilities (Seyed, Salmani, Nezhad, \& Noruzi, 2017), students interest (Alfa \& Karim, 2016), teaching methods (Asante \& Mereku, 2012), school entry modalities (Cameson \& Wilson, 2011), and to Gender (Cunningham, 2016). Studies are fast refuting many past beliefs that males perform better than females (Abubakar, 2010; Erdoğan, Baloğlu, \& Kesici, 2011) and prompting more investigations.

The world is fast changing due to science and technology hence the emphasis on training of teachers in the field of science, technology and Mathematics through regular, sandwich and DE modes. The aim of the DE programme in Ghana is therefore to ensure that quality education is made more accessible and relevant to the learning needs that can promote quality of lives of Ghanaians (Government of Ghana, 2002). This crucial aim seems to have suffered a setback for lack of clarity and limited research especially into the mathematics achievement of distance learners. In particular, while students' population in the DE programmes keeps increasing exponentially over the years (Larkai et al, 2016), not many studies have been conducted to explore the mathematical achievement of male and female distance education students.

Forgasız (2005) cited in Halat and Şahin (2008) argues that "it is significantly important to include gender as a variable in research analysis even if it is not the main focus of the study" (p. 148). In the views of Gunderson et al. (2012), negative attitudes of females in mathematics can prevent them from performing at their best and inhibit thier pursuit of mathematics-related career paths.

By its nature, it can be argued that DE programme exerts greater demand on both males and females who usually combine their profession roles with studies. The demand becomes much more challenging for females who spend most of their time caring for their children, cooking and doing house chores in lieu of studying. This may cause the gender gap in mathematics achievement of the DE learners. These arguments motivated the researchers to examine the gender variable in this present study. 


\section{Purpose of the Study}

UNESCO (2002) points out that open and distance learning gives access to education and training provision, frees learners from the constraints of time and place, and offers flexible learning opportunities to individuals and groups of learners. DE practitioners have shown interest in exploring the achievements of learners as well as opportunities that the learners have. The frequently asked question is however whether DE is effective. Historically, males have been reported to have higher levels of mathematics achievement than females. Results of achievement tests given to basic and high school students indicate that this gender gap has closed in recent years (Duckworth \& Seligman, 2006). Nevertheless, gender differences persist between students in advanced mathematics courses (Plummer, 2000) or in mathematics related careers (Przymus, 2004). Against this background, this study sought to examine any differences in mathematics achievement between male and female learners in DE programme.

\section{METHODOLOGY}

\section{Research Design}

The study employed Ex post facto research design as a strategy of enquiry. As Cooper and Schindler (2001) put it, Ex post facto research "is a method of teasing out possible antecedents of events that have happened and cannot, therefore, be controlled, engineered or manipulated by the investigator" (p. 136). In this study the researchers could only report what has happened by attempting to hold factors constant by careful attention to the sampling. The researchers found it expedient to use this design because the independent variable or variables in this study have already occurred (Kerlinger, 1970) thus, starting with the observation of a dependent variable (i.e. distance learners achievement grades) was key. In this sense the researchers studied the distance learners' performance in mathematics by using their achievement grades retrieved from the UEW-IDeL registry. Most importantly, the significance of differences between male and female distance learners were examined.

\section{Participants and Setting}

The population for this study was all DBE distance learners. These are pre-service teachers who are offering the UEW-IDeL programme in all the 40 study centers in Ghana. The ages of most of these learners are between 20 and 35 years. Almost every ethnicity in Ghana is found in each study center. The pre-service teachers in the UEW-IDeL DBE programme are trained with the same curriculum and run the same academic calendar as the regular students in UEW. These pre-service teachers have studied Mathematics in Ghana at the SHS level and have all passed either the Senior Secondary School Certificate Examination (SSSCE) or the West African Senior School Certificate Examination (WASSCE). However, majority of them enter the DBE programme with very low grades in Mathematics. These pre-service teachers have similar characteristics in terms of multiple ethnicities, age differentials, admission requirements and certification as the regular students. Furthermore, most of the part-time tutors who handle these preservice teachers in the various study centers hold qualified certificates from the two major teacher training Universities in Ghana namely, University of Education, Winneba (UEW) and the University of Cape Coast (UCC).
Table 1. Distance Learners' Grades and Interpretation

\begin{tabular}{cccc}
\hline Grade & Range & Remark & Point \\
\hline A & $80-100$ & Excellent & 4.0 \\
\hline B+ & $75-79$ & Very Good & 3.5 \\
\hline B & $70-74$ & Good & 3.0 \\
\hline C + & $65-69$ & Very Fair & 2.5 \\
\hline C & $60-64$ & Fair & 2.0 \\
\hline D+ & $55-59$ & Satisfactory & 1.5 \\
\hline D & $50-54$ & Barely satisfactory & 1.0 \\
\hline E & $0-49$ & Fail & 0.5
\end{tabular}

\section{Sample and Sampling Technique}

Considering the diverse nature of the population and the researchers' conviction that examining learners' achievement in three consecutive years could comprehensively clarify gender difference, the 2015, 2016 and 2017 year groups were purposively retrieved from IDeL registry. There were 6,468, 3,483 and 3,276 distance learners in the 2015, 2016 and 2017 year groups respectively. This gives a sample size of 13,227 distance learners in all. These learners have all studied two mathematics courses titled Mathematics for the Basic School Teacher I (Math I) and Mathematics for the Basic School Teacher II (Math II) in their DBE programme and have their achievement scores stored at the IDeL registry.

\section{Data Collection}

A letter seeking permission to access DBE learners' End-ofsemester examination scores and grades in Math I and II from 2015 to 2017 was granted by the head of the UEW-IDeL registry section. The data file containing achievement scores and grades were released for the purpose the study. The grades are interpreted according to UEW guidelines as shown in Table 1.

\section{Analysis of Data}

The data file was exported into Statistical Package for Social Science (SPSS) software and variables of course type, grades and gender defined and coded for analysis. The researchers found SPSS user friendly and suitable for the proposed analysis (Muijs, 2004). The data collected were analyzed using mainly the Chi-square tests of distributions of grades by gender. The Chi-square test was deemed suitable because there were two independent categorical variables of gender and grade. Gender was measured on two levels (i.e. males and females) while grade was measured on eight levels (i.e. A, B+, B, C+, C, D+, D and E). In this sense, the data consisted of frequencies of discrete categories and the study objective was to determine the significance of differences between the categories. Bar chart and contingency tables were obtained to examine the frequency distributions of grades by gender. To test for significant differences in the mathematics achievement between male and female distance learners for the three year groups, the Chi-square tests were set at .05 level of significance.

\section{RESULTS}

The results of the analysis of data are presented descriptively in this section based on DBE learners' year by year achievements as shown in Figure 1.

Figure 1 shows the achievement grades of the male and female distance learners in mathematics for the three consecutive years i.e. 


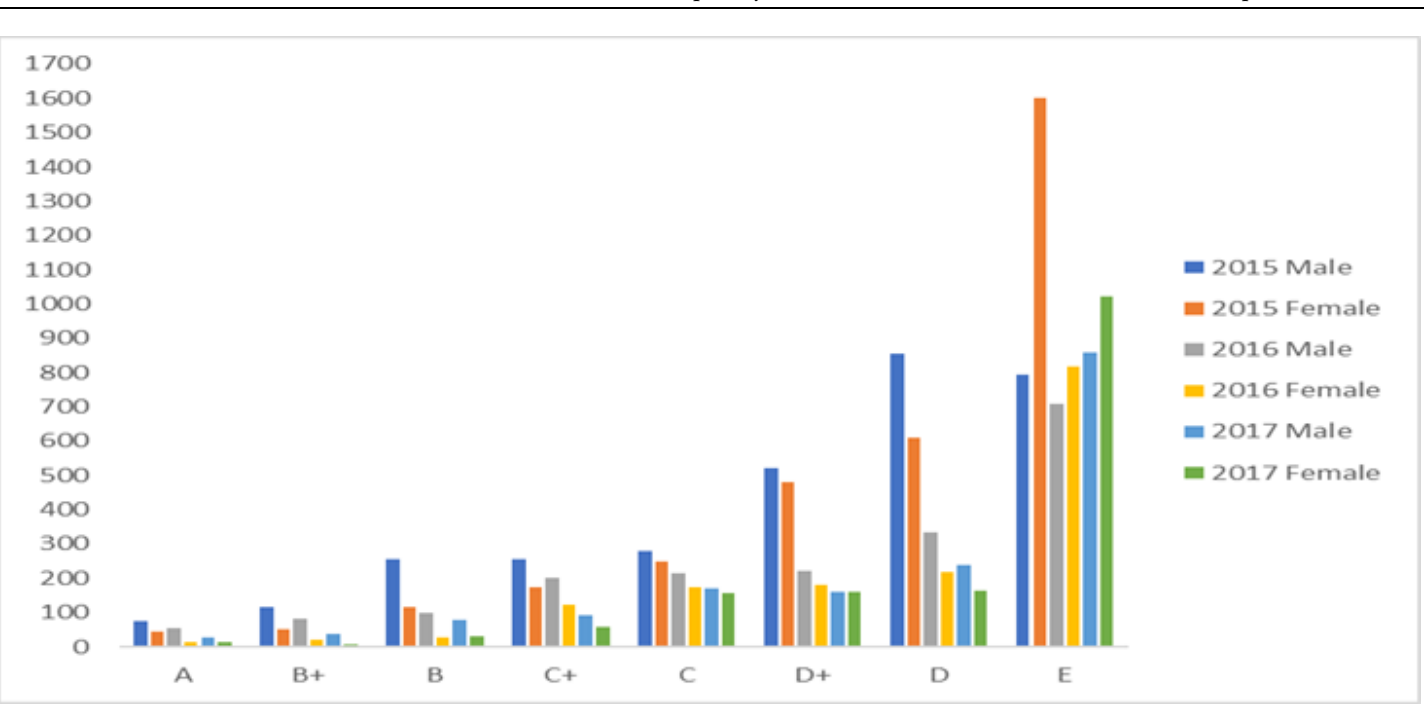

Figure 1. Male and female distance learners' mathematics achievement for the three years

Table 2. Contingency Table of Gender and Grade for 2015 year-group

\begin{tabular}{|c|c|c|c|c|}
\hline & \multirow{2}{*}{ Grade } & \multicolumn{2}{|c|}{ Gender } & \multirow{2}{*}{ Total } \\
\hline & & Female & Male & \\
\hline \multirow{5}{*}{ A } & Count & 43 & 76 & 119 \\
\hline & Expected Count & 61.1 & 57.9 & 119.0 \\
\hline & \% within Grade & $36.1 \%$ & $63.9 \%$ & $100.0 \%$ \\
\hline & \% within Gender & $1.3 \%$ & $2.4 \%$ & $1.8 \%$ \\
\hline & $\%$ of Total & $0.7 \%$ & $1.2 \%$ & $1.8 \%$ \\
\hline \multirow{5}{*}{$\mathrm{B}+$} & Count & 50 & 115 & 165 \\
\hline & Expected Count & 84.7 & 80.3 & 165.0 \\
\hline & $\%$ within Grade & $30.3 \%$ & $69.7 \%$ & $100.0 \%$ \\
\hline & \% within Gender & $1.5 \%$ & $3.7 \%$ & $2.6 \%$ \\
\hline & $\%$ of Total & $0.8 \%$ & $1.8 \%$ & $2.6 \%$ \\
\hline \multirow{5}{*}{ B } & Count & 116 & 254 & 370 \\
\hline & Expected Count & 189.9 & 180.1 & 370.0 \\
\hline & \% within Grade & $31.4 \%$ & $68.6 \%$ & $100.0 \%$ \\
\hline & \% within Gender & $3.5 \%$ & $8.1 \%$ & $5.7 \%$ \\
\hline & $\%$ of Total & $1.8 \%$ & $3.9 \%$ & $5.7 \%$ \\
\hline \multirow{5}{*}{$\mathrm{C}+$} & Count & 173 & 257 & 430 \\
\hline & Expected Count & 220.7 & 209.3 & 430.0 \\
\hline & \% within Grade & $40.2 \%$ & $59.8 \%$ & $100.0 \%$ \\
\hline & $\%$ within Gender & $5.2 \%$ & $8.2 \%$ & $6.6 \%$ \\
\hline & $\%$ of Total & $2.7 \%$ & $4.0 \%$ & $6.6 \%$ \\
\hline \multirow{5}{*}{$\mathrm{C}$} & Count & 249 & 280 & 529 \\
\hline & Expected Count & 271.5 & 257.5 & 529.0 \\
\hline & \% within Grade & $47.1 \%$ & $52.9 \%$ & $100.0 \%$ \\
\hline & $\%$ within Gender & $7.5 \%$ & $8.9 \%$ & $8.2 \%$ \\
\hline & $\%$ of Total & $3.8 \%$ & $4.3 \%$ & $8.2 \%$ \\
\hline
\end{tabular}

2015, 2016 and 2017. The number of male and female learners attaining the achievement grades for the various years is displayed. As can be seen from the figure, only few learners attained higher grades (i.e. grades $\mathrm{A}$, $\mathrm{B}+$, and $\mathrm{B}$ ). Majority of the distance learners attained lower grades (i.e. grades $\mathrm{D}+, \mathrm{D}$ and $\mathrm{E}$ ) putting them at a below average performance level. Even though the performance was abysmal, Figure 1 shows that for almost every year, the male distance learners outperformed the females in mathematics. To further ascertain the differences in their achievement and any significant gender differences in each cohort, contingency tables and Chi-square tests were examined as follows.

Differences between Male and Female Distance Learners' Achievement in Mathematics for 2015 year-group
Table 2 (continued). Contingency Table of Gender and Grade for 2015 year-group

\begin{tabular}{|c|c|c|c|c|}
\hline & \multirow{2}{*}{ Grade } & \multicolumn{2}{|c|}{ Gender } & \multirow{2}{*}{ Total } \\
\hline & & Female & Male & \\
\hline \multirow{5}{*}{$\mathrm{D}+$} & Count & 479 & 520 & 999 \\
\hline & Expected Count & 512.8 & 486.2 & 999.0 \\
\hline & \% within Grade & $47.9 \%$ & $52.1 \%$ & $100.0 \%$ \\
\hline & $\%$ within Gender & $14.4 \%$ & $16.5 \%$ & $15.4 \%$ \\
\hline & $\%$ of Total & $7.4 \%$ & $8.0 \%$ & $15.4 \%$ \\
\hline \multirow{5}{*}{$\mathrm{D}$} & Count & 608 & 854 & 1462 \\
\hline & Expected Count & 750.4 & 711.6 & 1462.0 \\
\hline & \% within Grade & $41.6 \%$ & $58.4 \%$ & $100.0 \%$ \\
\hline & $\%$ within Gender & $18.3 \%$ & $27.1 \%$ & $22.6 \%$ \\
\hline & $\%$ of Total & $9.4 \%$ & $13.2 \%$ & $22.6 \%$ \\
\hline \multirow{5}{*}{$\mathrm{E}$} & Count & 1602 & 792 & 2394 \\
\hline & Expected Count & 1228.8 & 1165.2 & 2394.0 \\
\hline & \% within Grade & $66.9 \%$ & $33.1 \%$ & $100.0 \%$ \\
\hline & $\%$ within Gender & $48.3 \%$ & $25.2 \%$ & $37.0 \%$ \\
\hline & $\%$ of Total & $24.8 \%$ & $12.2 \%$ & $37.0 \%$ \\
\hline \multirow{5}{*}{ Total } & Count & 3320 & 3148 & 6468 \\
\hline & Expected Count & 3320.0 & 3148.0 & 6468.0 \\
\hline & \% within Grade & $51.3 \%$ & $48.7 \%$ & $100.0 \%$ \\
\hline & $\%$ within Gender & $100.0 \%$ & $100.0 \%$ & $100.0 \%$ \\
\hline & $\%$ of Total & $51.3 \%$ & $48.7 \%$ & $100.0 \%$ \\
\hline
\end{tabular}

Table 2 presents the $2 \times 8$ contingency table showing the actual and expected counts as well as within gender and within grade percentage distributions of DE learners in this study. As can be seen from the table, there are differences in the distribution. For example, 43 females had grade A but less (i.e. 61.1) were expected, whereas, 76 males had A when less (i.e. 57.9) were expected. Also, the actual count for female distance learners who had grade B+ was 50 with an expected count of 84.7, whilst 115 male distance learners had grade $B+$ with an expected count of 80.3. The actual count of female distance learners who had grade D was 608 with an expected count of 750.4. Similarly, for the male distance learners, there were 854 with an expected count of 711.6. For grade E, there were 1602 female distance learners although 1228.8 were expected, however 792 came from the males when 1165.2 were expected.

To ascertain whether these differences are significant, the chisquare test was performed at 0.05 level of significance. Table 3 presents 
Table 3. Results from Chi-square Tests (for 2015-year group)

\begin{tabular}{cccc}
\hline & Value & Df & Asymp. Sig. (2-sided) \\
\hline Pearson Chi-Square & 417.310 & 7 & 0.000 \\
\hline Likelihood Ratio & 424.897 & 7 & 0.000 \\
\hline N of Valid Cases & 6468 & & \\
\hline
\end{tabular}

${ }^{*} 0$ cells $(0.0 \%)$ have expected count less than 5 . The minimum expected count is 57.92

Table 4. Contingency Table of Gender and Grade for 2016 year-group

\begin{tabular}{|c|c|c|c|c|}
\hline & \multirow{2}{*}{ Grade } & \multicolumn{2}{|c|}{ Gender } & \multirow{2}{*}{ Total } \\
\hline & & Female & Male & \\
\hline \multirow{5}{*}{ A } & Count & 15 & 53 & 68 \\
\hline & Expected Count & 30.7 & 37.3 & 68.0 \\
\hline & \% within Grade & $22.1 \%$ & $77.9 \%$ & $100.0 \%$ \\
\hline & \% within Gender & $1.0 \%$ & $2.8 \%$ & $2.0 \%$ \\
\hline & $\%$ of Total & $0.4 \%$ & $1.5 \%$ & $2.0 \%$ \\
\hline \multirow{5}{*}{$\mathrm{B}+$} & Count & 19 & 82 & 101 \\
\hline & Expected Count & 45.6 & 55.4 & 101.0 \\
\hline & \% within Grade & $18.8 \%$ & $81.2 \%$ & $100.0 \%$ \\
\hline & \% within Gender & $1.2 \%$ & $4.3 \%$ & $2.9 \%$ \\
\hline & $\%$ of Total & $0.5 \%$ & $2.4 \%$ & $2.9 \%$ \\
\hline \multirow{5}{*}{ B } & Count & 26 & 99 & 125 \\
\hline & Expected Count & 56.4 & 68.6 & 125.0 \\
\hline & \% within Grade & $20.8 \%$ & $79.2 \%$ & $100.0 \%$ \\
\hline & \% within Gender & $1.7 \%$ & $5.2 \%$ & $3.6 \%$ \\
\hline & $\%$ of Total & $0.7 \%$ & $2.8 \%$ & $3.6 \%$ \\
\hline \multirow{5}{*}{$\mathrm{C}+$} & Count & 124 & 200 & 324 \\
\hline & Expected Count & 146.1 & 177.9 & 324.0 \\
\hline & \% within Grade & $38.3 \%$ & $61.7 \%$ & $100.0 \%$ \\
\hline & \% within Gender & $7.9 \%$ & $10.5 \%$ & $9.3 \%$ \\
\hline & $\%$ of Total & $3.6 \%$ & $5.7 \%$ & $9.3 \%$ \\
\hline \multirow{5}{*}{$\mathrm{C}$} & Count & 173 & 213 & 386 \\
\hline & Expected Count & 174.1 & 211.9 & 386.0 \\
\hline & \% within Grade & $44.8 \%$ & $55.2 \%$ & $100.0 \%$ \\
\hline & $\%$ within Gender & $11.0 \%$ & $11.1 \%$ & $11.1 \%$ \\
\hline & $\%$ of Total & $5.0 \%$ & $6.1 \%$ & $11.1 \%$ \\
\hline \multirow{5}{*}{$\mathrm{D}+$} & Count & 180 & 223 & 403 \\
\hline & Expected Count & 181.8 & 221.2 & 403.0 \\
\hline & \% within Grade & $44.7 \%$ & $55.3 \%$ & $100.0 \%$ \\
\hline & $\%$ within Gender & $11.5 \%$ & $11.7 \%$ & $11.6 \%$ \\
\hline & $\%$ of Total & $5.2 \%$ & $6.4 \%$ & $11.6 \%$ \\
\hline \multirow{5}{*}{$\mathrm{D}$} & Count & 217 & 335 & 552 \\
\hline & Expected Count & 249.0 & 303.0 & 552.0 \\
\hline & \% within Grade & $39.3 \%$ & $60.7 \%$ & $100.0 \%$ \\
\hline & $\%$ within Gender & $13.8 \%$ & $17.5 \%$ & $15.8 \%$ \\
\hline & $\%$ of Total & $6.2 \%$ & $9.6 \%$ & $15.8 \%$ \\
\hline \multirow{5}{*}{ E } & Count & 817 & 707 & 1524 \\
\hline & Expected Count & 687.4 & 836.6 & 1524.0 \\
\hline & \% within Grade & $53.6 \%$ & $46.4 \%$ & $100.0 \%$ \\
\hline & \% within Gender & $52.0 \%$ & $37.0 \%$ & $43.8 \%$ \\
\hline & $\%$ of Total & $23.5 \%$ & $20.3 \%$ & $43.8 \%$ \\
\hline \multirow{5}{*}{ Total } & Count & 1571 & 1912 & 3483 \\
\hline & Expected Count & 1571.0 & 1912.0 & 3483.0 \\
\hline & \% within Grade & $45.1 \%$ & $54.9 \%$ & $100.0 \%$ \\
\hline & \% within Gender & $100.0 \%$ & $100.0 \%$ & $100.0 \%$ \\
\hline & $\%$ of Total & $45.1 \%$ & $54.9 \%$ & $100.0 \%$ \\
\hline
\end{tabular}

the results for the 2015 year-group of distance learners. As can be seen from this table the test reveals that there is statistically significant gender difference in the Mathematics achievement in favour of male distance learners $\left(\chi^{2}=417.310 ; d f=7 ; p<0.05\right)$.
Table 5. Results from Chi-square Tests (for 2016 year-group)

\begin{tabular}{cccc}
\hline & Value & Df & Asymp. Sig. (2-sided) \\
\hline Pearson Chi-Square & 130.757 & 7 & 0.000 \\
\hline Likelihood Ratio & 136.994 & 7 & 0.000 \\
\hline N of Valid Cases & 3483 & & \\
\hline
\end{tabular}

*0 cells $(0.0 \%)$ have expected count less than 5 . The minimum expected count is 30.7

\section{Differences between Male and Female Distance Learners Achievement in Mathematics for 2016 year-group}

Similarly, contingency table and chi-square test were run and used to investigate whether there was a statistically significant difference in the achievement of Mathematics between male and female distance learners for the 2016 year-group. Table 4 presents the $2 \times 8$ contingency table showing the actual and expected counts as well as within gender and within grade percentages of the distribution. The result shows there are differences in the distribution. For example, 15 females had grade A but less (i.e. 30.7) were expected, whereas, 53 males had grade A when less (i.e. 37.3) were expected. Also the actual count for female distance learners who had grade $\mathrm{B}+$ was 19 with an expected count of 45.6, whilst 82 male distance learners had grade $B+$ with an expected count of 55.4. The actual count of female distance learners who had grade D was 217 with an expected count of 249.0, for the male distance learners, there were 335 with an expected count of 303.0. For grade E, there were 817 female distance learners although 687.4 were expected and finally, 707 came from the males when 836.6 were expected.

Table 5 presents the results of the chi-square test for 2016 yeargroup of distance learners. From this table the test shows there is statistically significant gender difference in the achievement in Mathematics favouring male distance learners $\left(\chi^{2}=130.757 ; d f=7 ; p<\right.$ 0.05).

\section{Differences between Male and Female Distance Learners'} Achievement in Mathematics for 2017 year-group

Difference in the Mathematics achievement between male and female distance learners for the 2017-year group was also examined using the contingency table and statistical significance difference test with chi-square test at 0.05 level. Table 6 presents the $2 \times 8$ contingency table showing the actual and expected counts as well as within gender and within grade percentages of the distribution. The results show that there are differences in the distribution. For example, 12 females had grade A but less (i.e. 19.7) were expected, whereas, 28 males had A when less (i.e. 20.3) were expected. Also, the actual count for female distance learners who had grade $B+$ was 8 with an expected count of 23.1, whilst 39 male distance learners had grade B+ with an expected count of 23.9. The actual count of female distance learners who had grade D was 164 with an expected count of 197.7, for the male distance learners, there were 238 with an expected count of 204.3. For grade E, there were 1023 female distance learners although 925.0 were expected, however 858 came from the males when 956.0 were expected.

Table 7 presents the results of the chi-square test for 2017-year group of distance learners. The test shows that there is statistically significant gender difference in the Mathematics achievement favouring males $\left(\chi^{2}=83.113 ; d f=7 ; p<0.05\right)$.

In summary, the entire analysis of results indicates significant differences in the achievement of Mathematics between male and female distance learners who offer UEW-IDeL DBE programme in the 
Table 6. Contingency Table of Gender and Grade for 2017 year-group

\begin{tabular}{|c|c|c|c|c|}
\hline & \multirow{2}{*}{ Grade } & \multicolumn{2}{|c|}{ Gender } & \multirow{2}{*}{ Total } \\
\hline & & Female & Male & \\
\hline \multirow{5}{*}{ A } & Count & 12 & 28 & 40 \\
\hline & Expected Count & 19.7 & 20.3 & 40.0 \\
\hline & \% within Grade & $30.0 \%$ & $70.0 \%$ & $100.0 \%$ \\
\hline & $\%$ within Gender & $0.7 \%$ & $1.7 \%$ & $1.2 \%$ \\
\hline & $\%$ of Total & $0.4 \%$ & $0.9 \%$ & $1.2 \%$ \\
\hline \multirow{5}{*}{$\mathrm{B}+$} & Count & 8 & 39 & 47 \\
\hline & Expected Count & 23.1 & 23.9 & 47.0 \\
\hline & \% within Grade & $17.0 \%$ & $83.0 \%$ & $100.0 \%$ \\
\hline & \% within Gender & $0.5 \%$ & $2.3 \%$ & $1.4 \%$ \\
\hline & $\%$ of Total & $0.2 \%$ & $1.2 \%$ & $1.4 \%$ \\
\hline \multirow{5}{*}{ B } & Count & 30 & 77 & 107 \\
\hline & Expected Count & 52.6 & 54.4 & 107.0 \\
\hline & \% within Grade & $28.0 \%$ & $72.0 \%$ & $100.0 \%$ \\
\hline & \% within Gender & $1.9 \%$ & $4.6 \%$ & $3.3 \%$ \\
\hline & $\%$ of Total & $0.9 \%$ & $2.4 \%$ & $3.3 \%$ \\
\hline \multirow{5}{*}{$\mathrm{C}+$} & Count & 59 & 93 & 152 \\
\hline & Expected Count & 74.7 & 77.3 & 152.0 \\
\hline & \% within Grade & $38.8 \%$ & $61.2 \%$ & $100.0 \%$ \\
\hline & \% within Gender & $3.7 \%$ & $5.6 \%$ & $4.6 \%$ \\
\hline & $\%$ of Total & $1.8 \%$ & $2.8 \%$ & $4.6 \%$ \\
\hline \multirow{5}{*}{$\mathrm{C}$} & Count & 155 & 171 & 326 \\
\hline & Expected Count & 160.3 & 165.7 & 326.0 \\
\hline & \% within Grade & $47.5 \%$ & $52.5 \%$ & $100.0 \%$ \\
\hline & $\%$ within Gender & $9.6 \%$ & $10.3 \%$ & $10.0 \%$ \\
\hline & $\%$ of Total & $4.7 \%$ & $5.2 \%$ & $10.0 \%$ \\
\hline \multirow{5}{*}{$\mathrm{D}+$} & Count & 160 & 161 & 321 \\
\hline & Expected Count & 157.9 & 163.1 & 321.0 \\
\hline & \% within Grade & $49.8 \%$ & $50.2 \%$ & $100.0 \%$ \\
\hline & $\%$ within Gender & $9.9 \%$ & $9.7 \%$ & $9.8 \%$ \\
\hline & $\%$ of Total & $4.9 \%$ & $4.9 \%$ & $9.8 \%$ \\
\hline \multirow{5}{*}{$\mathrm{D}$} & Count & 164 & 238 & 402 \\
\hline & Expected Count & 197.7 & 204.3 & 402.0 \\
\hline & \% within Grade & $40.8 \%$ & $59.2 \%$ & $100.0 \%$ \\
\hline & $\%$ within Gender & $10.2 \%$ & $14.3 \%$ & $12.3 \%$ \\
\hline & $\%$ of Total & $5.0 \%$ & $7.3 \%$ & $12.3 \%$ \\
\hline \multirow{5}{*}{ E } & Count & 1023 & 858 & 1881 \\
\hline & Expected Count & 925.0 & 956.0 & 1881.0 \\
\hline & \% within Grade & $54.4 \%$ & $45.6 \%$ & $100.0 \%$ \\
\hline & $\%$ within Gender & $63.5 \%$ & $51.5 \%$ & $57.4 \%$ \\
\hline & $\%$ of Total & $31.2 \%$ & $26.2 \%$ & $57.4 \%$ \\
\hline \multirow{5}{*}{ Total } & Count & 1611 & 1665 & 3276 \\
\hline & Expected Count & 1611.0 & 1665.0 & 3276.0 \\
\hline & \% within Grade & $49.2 \%$ & $50.8 \%$ & $100.0 \%$ \\
\hline & \% within Gender & $100.0 \%$ & $100.0 \%$ & $100.0 \%$ \\
\hline & $\%$ of Total & $49.2 \%$ & $50.8 \%$ & $100.0 \%$ \\
\hline
\end{tabular}

2015, 2016 and 2017 academic years. The differences were in favour of males in all three years.

\section{CONCLUSION}

Whereas distance education is said to have tremendous benefits in terms of delivering tertiary education, research is still limited about the
Table 7. Results from Chi-square Tests (for 2017 year-group)

\begin{tabular}{cccc}
\hline & Value & Df & Asymp. Sig. (2-sided) \\
\hline Pearson Chi-Square & 83.113 & 7 & 0.000 \\
\hline Likelihood Ratio & 85.980 & 7 & 0.000 \\
\hline N of Valid Cases & 3276 & & \\
\hline
\end{tabular}

*0 cells $(0.0 \%)$ have expected count less than 5 . The minimum expected count is 19.67

gender difference in Mathematics achievement of distance learners especially in Ghana. The present study examined this gender difference by comparing the mathematics achievement of 6502 males and 6725 females offering diploma in Basic Education by distance at UEW-IDeL DBE for 2015, 2016 and 2017 academic years.

Generally, both male and female distance learners produced a below average performance in Mathematics with majority attaining lower grades i.e. D+, D and E. The study however, found that both genders differed significantly in mathematics grades - with the male distance learners attaining higher grades than their female counterparts. This finding is consistent with that of Cunningham (2016), who found that male students achieved relatively high in mathematics compared to their female counterparts. The finding was however, divergent from those of Abubakar and Oguguo (2011) as well as Erdoğan, Baloğlu and Kesici (2011). As Abubakar and Oguguo (2011) reported that no significant difference existed between gender and mathematics achievement, Erdoğan, Baloğlu and Kesici (2011) recounted significant gender differences in mathematics achievement, emphasizing that females achieved significantly higher than males.

Researchers (Plummer, 2000; Przymus, 2004) have indicated that females in distance learning are under-represented in science, technology, technical and mathematics oriented courses. This could indicate that females have some challenges with respect to these areas of study thus their low representation. In this study the abysmally low performance of female distance learners may probably be due to the fact that they entered the programme with relatively lower grades in mathematics as reported in literature (IDeL Admission Brochure, 2019).

The implication of this is that more females may be moving away from the teaching of mathematics. With the current student population becoming more and more diverse, the demand for teachers especially for the teaching of mathematics in basic schools has never been greater. The provision of teacher education through the usual college of education and university regular programme has not been adequate. In fact, distance education programmes have been suggested by many educators as the panacea to this problem (Larkai, 2014; Larkai et al., 2016; Pityana, 2004). It is therefore recommended that teacher education institutions should pay special attention to the mathematics teaching of female learners especially in their distance education programmes and motivate them to pursue the subject. It would also be expedient for mathematics tutors to be more sensitive to gender differences when teaching and also for stakeholders to encourage female prospective teachers in mathematics teaching and learning.

This study was limited to only DBE distance education learners hence, it is important to indicate that these conclusions are based purely on achievement grades of these cohorts of distance learners. It is also worth bearing in mind that although the results provided information on the distance learners' achievement in mathematics, the observed achievements can only be partial representations of the entire 
achievements of the learners in the UEW-IDeL programme. Even though this study has shown that male distance learning students perform better in mathematics than their female colleagues, further research needs to be conducted with other universities in order to have a more general picture of the distance learners' mathematics achievement and gender.

\section{REFERENCES}

Abubakar, R. B. (2010). Qualitative and Functional Mathematics Education, Does Age and Gender affects Academic performance? Proceedings of the 47th Annual National Conference of Mathematics Association of Nigeria (MAN) held at Nasarawa State Polytechnic, Lafia between 28th August -3rd September, 210-215.

Abubakar, R. B., \& Oguguo, O. D. (2011). Age and gender as predictors of academic achievement of college mathematics and science students. Proceedings of the 2011, International Conference on Teaching, Learning and Change.

Alfa, A. B., \& Karim, M. Z. A. (2016). Student Enthusiasm as a Key Determinant of their Performance. International Review of Management and Marketing, 6(2), 237-245.

Anamuah-Mensah, J., \& Mereku, D. K. (2005). Ghanaian Junior Secondary School two students abysmal Mathematics Achievement in TIMSS 2003: A consequence of the Basic school Mathematics. Mathematics Connection, 5(1), 1-11. https://doi.org/10.4314/ mc.v5i1.21489

Anamuah-Mensah, J., Mereku, D. K., \& Asabere-Ameyaw, A. (2008). Ghanaian Junior Secondary School Students' Achievement in Mathematics and Science: Results from Ghana's participation in the 2007 Trends in International Mathematics and Science Study. Accra: Ministry of Education Youth and Sports.

Asante, J. N., \& Mereku, D. K. (2012). The Effect of Ghanaian Preservice Teachers' Content Knowledge on their Mathematical Knowledge for teaching Basic School Mathematics. African Journal of Educational Studies in Mathematics and Sciences, 10, 23-37.

Barakzai, M. D., \& Fraser, D. (2005). The Effect of Demographic Variables on Achievement in and Satisfaction with Online Coursework. Journal of Nursing Education, 44(8), 373-380. https://doi.org/10.3928/01484834-20050801-08

Butakor, P. K., Ampadu, E., \& Cole, Y. (2017). Ghanaian Students in TIMSS 2011: Relationship between Contextual Factors and Mathematics Performance. https://doi.org/10.1080/18117295. 2017.1379281

Cameson, M. B., \& Wilson, B. J. (2011). Effect of chronological age, gender and delay of entry on academic achievement and retention. Implications for academic redshirting. Psychology in the Schools, 27(3), 260-263. https://doi.org/10.1002/1520-6807(199007)27:3< 260::AID-PITS2310270313>3.0.CO;2-V

Cheung, L. L. W., \& Kan, A. (2002). Evaluation of Factors Related to Student Performance in Distance-Learning Business Communication Course. Journal of Education for Business, 77(5), 257 263. https://doi.org/10.1080/08832320209599674

Cooper, D. C., \& Schindler, P. S. (2001). Business Research Methods $\left(7^{\text {th }}\right.$ Ed.). New York: McGraw-Hill.
Cunningham, M. (2016). The Gender Paradox in School Mathematics. Alberta Journal of Educational Research, 4(62), 369-388.

Duckworth, A. L., \& Seligman, M. E. P. (2006). Self-discipline gives girls the edge: gender in self-discipline, grades, and achievement test scores. Journal of Educational Psychology, 98(1), 198-208. https://doi.org/10.1037/0022-0663.98.1.198

Erdoğan, A., Baloğlu, M., \& Kesici, Ş. (2011). Gender differences in geometry and mathematics achievement and self-efficacy beliefs in geometry. Egitim Arastirmalari-Eurasian Journal of Educational Research, 43, 188-205.

Government of Ghana (2002). Meeting the Challenges of Education in the Twenty First Century. Report of the President's Committee on Review of Education Reforms in Ghana. Accra: Government of Ghana.

Gunderson, E. A., Ramirez, G., Levine, S. C., \& Beilock, S. L. (2012). The Role of Parents and Teachers in the Development of GenderRelated Math Attitudes. Sex Roles, 66, 153-166. https://doi.org/10.1007/S11199-011-9996-2

Gunhan, B. C. (2014). A Case Study on the investigation of reasoning skills in Geometry. South African Journal of Education, 34(2) 1-19. https://doi.org/10.15700/201412071156

Halat, E., \& Şahin, O. (2008). Van Hiele Levels of Pre- and In- Service Turkish Elementary School Teachers and Gender Related Differences in Geometry. The Mathematics Educator, 11(1/2), 143158.

Institute for Distance and e-Learning (IDeL) (2019). Admission Brochure. University of Education, Winneba. Winneba-Ghana. Retrieved from https://www.uew.edu.gh/sites/default/files/downloads/ Admission\%20Brochure\%20IDeL-web.pdf

Kerlinger, F. N. (1970). Foundations of Behavioral Research. New York: Holt, Rinehart \& Winston.

Larkai, A. T. (2014). Distance Learning in Ghana - Employing Innovation to Combat Accessibility, Poster Presentation, Going Global, May 2014, Miami.

Larkai, A. T., Ankomah-Asare, E. T., \& Nsowah-Nuamah, N. N. N. (2016). Distance Education in Ghana: An overview of enrolment and Programme Patterns. Proceedings of INCEDI 2016 Conference 29th-31st August 2016, Accra, Ghana

Mensah, S. K. E., \& Owusu-Mensah, F. (2002). Priorities and Strategies for Capacity Building in Tertiary Distance Education for Human Resource Development in Ghana. A final report prepared for the World Bank.

Muijs, D. (2004). Doing Quantitative Research in Education with SPSS. London: SAGE Publishers Ltd. https://doi.org/10.4135/ 9781849209014

Mullis, I. V. S., Martin, M. O., \& Foy, P. (2008). TIMSS 2007 International Mathematics Report: Findings from IEA's International Trends in Mathematics and Science Study at Fourth and Eighth Grades. TIMSS \& PIRLS International Study Center, Lynch School of Education, Boston College.

Pityana, B. N. (2004). Open distance learning in Africa: Access, quality and success. South Africa: UNISA.

Plummer, V. C. (2000). Women and Distance Education. London: Routledge. 
Przymus (2004). A simple way to increase persistence in distance education. Women in Higher Education, 13(1), 35-46. https://doi.org/10.4314/just.v31i1.64890

Seyed, S., Salmani, M., Nezhad, F. M., \& Noruzi, R. (2017). Self-Efficacy, Achievement Motivation, and Academic Progress of Students with Learning Disabilities: A Comparison with Typical Students. https://doi.org/10.5812/mejrh.44558
UNESCO (2002). Open and distance learning: Trend, policy and strategy considerations. Paris: UNESCO. Retrieved on 16 August 2020 from http://unesdoc.Unesco.org/image/0012/001284/ 128463e.pdf

Wedege, T. (2007). Gender perspectives in mathematics education: intentions of research in Denmark and Norway. The International Journal on Mathematics Education, 39, 251-260. https://doi.org/10.1007/s11858-007-0026-3 